\title{
Investigation of convectively generated gravity wave characteristics and generation mechanisms during the passage of thunderstorm and squall line over Gadanki $\left(13.5^{\circ} \mathrm{N}, 79.2^{\circ} \mathrm{E}\right)$
}

\author{
M. Arunachalam Srinivasan ${ }^{1}$, S. V. B. Rao ${ }^{1}$, and R. Suresh ${ }^{2}$ \\ ${ }^{1}$ Department of Physics, Sri Venkateswara University, Tirupati-517 502, India \\ ${ }^{2}$ India Meteorological Department, Chennai-600 001, India \\ Correspondence to: M. Arunachalam Srinivasan (arun82chalam2001@ yahoo.co.in)
}

Received: 26 April 2013 - Revised: 23 November 2013 - Accepted: 23 December 2013 - Published: 30 January 2014

\begin{abstract}
This study illustrates the convectively generated gravity wave generation mechanisms during the passage of thunderstorms and squall line using Indian MST radar. For the first time, it has been shown that all three generation mechanisms have been involved in the generation of gravity waves during the passage of squall line event. It is observed that the periodicities in the range of $8-80 \mathrm{~min}$ in the tropospheric and 8-32 min in the lower stratospheric regions and vertical wavelengths in the range of $3.2-4.8 \mathrm{~km}$ in the tropospheric and $1.2-1.92 \mathrm{~km}$ in the lower stratospheric regions are found to be dominant in the present study and are distinctly different during initial, mature and dissipative phases of convection. Amplitude of vertical wind has been weakened (from $\sim 4-6 \mathrm{~m} \mathrm{~s}^{-1}$ to $\sim 1 \mathrm{~m} \mathrm{~s}^{-1}$ ) considerably after 10$30 \mathrm{~min}$ of a convection event. It appears that the wind shear associated with the convective clouds acted like an obstacle to the mean background flow during the squall line passage generated gravity waves. The phase profiles corresponding to the dominant period show both downward and upward propagation of waves. The vertical extent of heating is found to be deeper during squall line event compared with thunderstorm event. From the phase profiles, during 27 September 2004, two peaks of constant phase region are observed. One is due to convective elements and the other is due to strong background wind shear; however, only one peak is observed on 29 September 2004, which is only due to convective processes.
\end{abstract}

Keywords. Electromagnetics (wave propagation) - meteorology and atmospheric dynamics (convective processes) radio science (atmospheric propagation)

\section{Introduction}

It is well known that gravity waves significantly affect various dynamical processes in the upper and middle atmosphere (Fritts and Alexander, 2003; Mohankumar, 2008). The convectively generated gravity waves (CGWs) play a key role in organizing convection and initiating new cells (Lin et al., 1998). Mapes and Houze Jr. (1995) suggested that vertical motions in a stably stratified atmosphere allied with buoyancy oscillations favor the triggering of the additional convection that is perceived to be the main initiating mechanism of gravity waves (GWs).

Convection plays a major role in generating GWs by releasing enormous amounts of latent heat and contributes to the wave mean flow interactions in the tropical middle atmosphere (Alexander, 1995; Pandya and Alexander, 1999). Upstream propagating waves will be produced when a convective cloud obstructs the mean flow (Clark et al., 1986; Pfister et al., 1993; Alexander and Vincent, 2000; Beres et al., 2002).

Convective instability creates oscillatory displacements in the isentropic/isobaric surfaces and generates GWs that propagate vertically as a harmonic oscillator (Clark et al., 1986; Fovell et al., 1992; Alexander, 1995; Alexander and Holton, 1997; Lane and Reeder, 2001; Dhaka et al., 2002, 2003; Kumar, 2006, 2007; Dutta et al., 2009). Based on two different convective events, Kumar (2007) studied the nonlinear interaction of GWs, finding periods of 28-12 $\min (35$ $15 \mathrm{~min})$ in the troposphere and $21-8.4 \mathrm{~min}(26 \mathrm{~min})$ in the lower stratosphere. Alexander (1995) simulated squall lines, observing harmonics with a period of around $23-28 \mathrm{~min}$ in the troposphere and $12.8-7.8 \mathrm{~min}$ in the stratosphere, 
attributing them to the mechanical oscillator effect. Dutta et al. (2009), have found significant periodicities between 8-15 $\mathrm{min}, 20-60 \mathrm{~min}$, and $60-80 \mathrm{~min}$ in the troposphere between 5-10 and $10-15 \mathrm{~km}$ and $12.5-15 \mathrm{~min}, 15-18 \mathrm{~min}$ and 20-70 min bands in the lower stratosphere (LS) between $17-22 \mathrm{~km}$. Numerical simulations performed by Beres et al. (2004), showed that periods between $10 \mathrm{~min}$ and $100 \mathrm{~min}$ are observed. In agreement with the results of Lane and Reeder (2001), Dhaka et al. (2002) observed the same location, GWs of $10-18 \mathrm{~min}$ in the LS region.

CGWs are quite important in tropics because of their efficient transport of surplus energy to sub-tropics by means of general circulation (Green, 1999). Hence, an appropriate parameterization scheme needs to be developed for application in the global climate models (Beres et al., 2002). There are several studies analyzing the structure and impact of CGWs in tropical regions (Dhaka et al., 2002, 2003; Kumar, 2006, 2007; Dutta et al., 2009). Although an attempt was made by Beres et al. (2002), a cross-sectional understanding of CGWs in the three phases of convection has not yet been gained.

The present study describes the characteristics of GWs in initial, mature and dissipative phases of convection. From Indian MST radar, the ECWF model and satellite data an attempt to find the dominant generation mechanism of CGWs during the passage of thunderstorms and squall lines over Gadanki is made.

\section{Data and methodology}

\subsection{MST radar data}

Radar observations are provided by the National Atmospheric Research Laboratory, Gadanki $\left(13.47^{\circ} \mathrm{N}, 79.18^{\circ} \mathrm{E}\right)$, between 10:30 LT (Local Time) on 27 September 2004 and 10:18 LT on 30 September 2004. We analyze two events of thunderstorm and squall line that took place over the studied location during this period: Event 1 on 27 September 2004 and Event 2 on 29 September 2004. Wind information obtained from radar data, which operated the vertical (Zenith$\mathrm{X}$, i.e., $\mathrm{Z}_{x}$ ) direction, in the six beam (viz., East (E), West $(\mathrm{W})$, Zenith (E-W polarization, i.e., $\mathrm{Z}_{x}$ ), Zenith $(\mathrm{N}-\mathrm{S}$ polarization, i.e., $Z_{y}$ ), North $(\mathrm{N})$, and South $(\mathrm{S})$ ) mode at an 8 $12 \mathrm{~h}$ interval. May and September months are likely for the observation of deep convective events such as thunderstorms over this part of the tropical region (Dutta et al., 2009). VHF radar located at Gadanki operates at $53 \mathrm{MHz}$ with an average power aperture product of $\sim 7 \times 10^{8} \mathrm{~W} \mathrm{~m}^{-2}$ and a narrow beam width of $3^{\circ}$. The technical specifications of Indian MST radar operating at VHF ranges at Gadanki $\left(13.47^{\circ} \mathrm{N}\right.$, $79.18^{\circ} \mathrm{E}$ ) have been furnished in Rao et al. (1995). Continuous observations of vertical velocities with a vertical resolution of $150 \mathrm{~m}$ and temporal resolution of $48 \mathrm{~s}$ and $38 \mathrm{~s}$ during events 1 and 2 have been utilized for the present study.

\subsection{Satellite observations of equivalent blackbody brightness temperature}

We have used the hourly cloud-top equivalent blackbody temperature, called brightness temperature, from Multifunctional Transport Satellite (MTSAT-1R) data provided by the Japan Meteorological Agency (JMA) through Kochi University, Japan. Data was recorded in a latitude-longitude grid $11.55^{\circ} \mathrm{N} / 77.2^{\circ} \mathrm{E}-15.5^{\circ} \mathrm{N} / 81.15^{\circ} \mathrm{E}$ with $0.05^{\circ}$ resolution covering the location of Gadanki. The black body brightness temperature (TBB) data, averaged from the pixel data, is used to examine the characteristics of synoptic-scale and mesoscale cloud systems. The occurrence of tropical convection during the studied period is inferred from this last information.

\subsection{ERA-Interim reanalysis data}

ERA-Interim reanalysis temperature data sets (Simmons et al., 2007) at 37 vertical levels from $1000 \mathrm{hPa}$ to $1 \mathrm{hPa}$ over the study area with a $1.5^{\circ} \times 1.5^{\circ}$ grid have been obtained for 00:00, 06:00, 12:00 and 18:00 UTC (Universal Time Coordinated $(\mathrm{UTC})=\mathrm{LT}-5.5 \mathrm{~h})$ from the portal http://www.esrl. noaa.gov.

\section{Results and discussions}

\subsection{Background meteorological conditions}

Figure 1 shows the cloud top brightness temperature (TBB) over Gadanki $\left(13.47^{\circ} \mathrm{N}, 79.18^{\circ} \mathrm{E}\right)$ and Chennai $\left(13.00^{\circ} \mathrm{N}\right.$, $80.18^{\circ} \mathrm{E}$ ) obtained from MTSAT-1R satellite measurements. We adopted the criteria from TBB of less than $235 \mathrm{~K}$ to demarcate deep convective clouds (Chen et al., 1996; Arkin and Meisner, 1987). It is noticed from Fig. 1 that there is deep convective activity over Gadanki and Chennai on the night of 27 September to the early morning of 28 September. $40 \mathrm{~mm}$ rainfall was also recorded by the rain gauge of IMD, Chennai observatory (Suresh, 2012), and $56 \mathrm{~mm}$ was recorded by the disdrometer at the MST radar site (Radhakrishna et al., 2009). Even though cumulonimbus (Cb) clouds were going through Gadanki (GDK) towards Chennai (MDS) on 29 September at 09:12 LT (03:42 UTC) and on 30 September at 17:42 LT (12:12 UTC, as in Fig. 2), no significant rainfall had been recorded at GDK. However, 3 to $5 \mathrm{~mm}$ was recorded at MDS. The rainfall information has been obtained from precipitation accumulation data retrieved from the Doppler Weather Radar (DWR) IMD, Chennai (Suresh, 2012).

The Doppler Weather Radar (DWR) reflectivity products of the India Meteorological Department (IMD), Chennai (Fig. 2) depict the existence of matured thunderstorm and squall line events over Gadanki. The maximum value of reflectivity (Max (Z)) product shows the value of reflectivity over each pixel of the cylindrical volume in its plane view. 


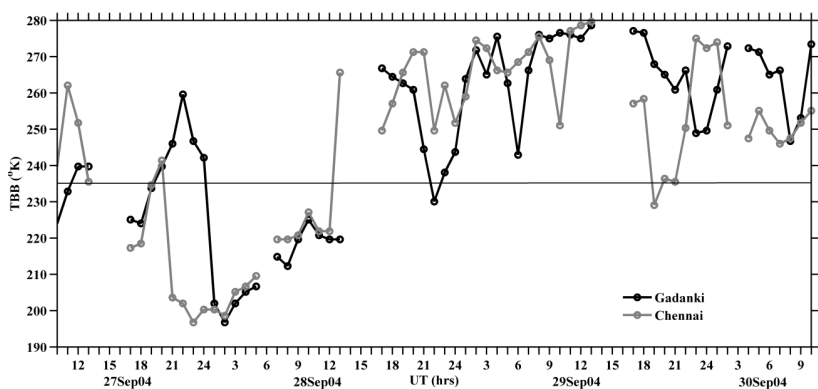

Fig. 1. Hourly cloud top brightness temperature (TBB, in K) over Gadanki (black) and Chennai (gray) for 27-30 September 2004. The line at $235 \mathrm{~K}$ indicates the threshold value of deep convective events.

The height corresponding to the maximum value of reflectivity through west to east can be found along the right-hand side display, and the height of maximum reflectivity when viewed from south to north is projected over the top. Cloud heights exceeding $6 \mathrm{~km}$ and reflectivity exceeding $45 \mathrm{dBZ}$ have been considered as thunderstorm/cumulonimbus $(\mathrm{Cb})$ cloud (Suresh and Bhatnagar, 2005). Based on these criteria, thunderstorm events were observed close to/around Gadanki during the observational period as follows:

i. On 27 September 2004 from 17:12 to 17:42 LT, $\mathrm{Cb}$ clouds with cloud tops $6-7 \mathrm{~km}$ over/near GDK (Fig. 2a) and squall line passage nearly $100-150 \mathrm{~km}$ between Salem (SLM) and GDK.

ii. On 29 September 2004 from 09:12 to 10:12 LT, squall line passage between MDS and GDK with cloud tops 15-16 km over/near GDK (Fig. 2b) and whose extreme tip was close to GDK (Fig. 2b).

Height-time intensity profile of signal to noise ratio (SNR), vertical wind velocity $\left(\mathrm{m} \mathrm{s}^{-1}\right)$, and spectral width $\left(\mathrm{m} \mathrm{s}^{-1}\right)$ derived from the vertical (MST) radar beam for 2730 September 2004 are shown in Fig. 3a-c. The events of passing of thunderstorm and squall line over GDK are clearly depicted in encircled ellipses in the figure. Within this encircled region, the SNR is found to be minimum during Event 1 at which the vertical velocities show strong downdrafts $\left(-6.4 \mathrm{~m} \mathrm{~s}^{-1}\right)$ compared with updrafts $\left(3.9 \mathrm{~m} \mathrm{~s}^{-1}\right)$. Even though there are strong updrafts $\left(4.5 \mathrm{~m} \mathrm{~s}^{-1}\right)$ and downdrafts $\left(-4.6 \mathrm{~m} \mathrm{~s}^{-1}\right)$ in the vertical velocity, the SNR minimum is not observed during Event 2. During the observational period there exist strong stratified layers $(\sim 0.5-2 \mathrm{~km})$ of turbulence associated with shear near the tropopause even when the spectral width was found to be strong. It may be noticed that convective overshooting was noticed particularly during Event 2, which may be evident from SNR and spectral width (encircled with ellipse, in between 08:00-12:00 LT on 29 September 2004).

Figure 4 shows the height-time contours of available background zonal wind $\left(\mathrm{m} \mathrm{s}^{-1}\right)$ (top), meridional $\left(\mathrm{m} \mathrm{s}^{-1}\right)$ wind (middle) and corresponding horizontal wind shear $\left(\mathrm{s}^{-1}\right)$ (bottom) for the present studied period. It may be noticed that the zonal wind shows a maximum easterly wind speed of about $\sim 28 \mathrm{~m} \mathrm{~s}^{-1}$ from 27-30 September 2004 over the $\sim 15-17 \mathrm{~km}$ height region. The easterly wind is higher than $25 \mathrm{~m} \mathrm{~s}^{-1}$ near the tropopause height and the meridional component shows strong southerly winds in the same height region $(\sim 15.5-16.5 \mathrm{~km})$, with a strong northerly component above this region. However, the southerly component was somewhat weaker during Event 1 compared with the remaining days. The time evolution of the southerly meridional wind (of the order of $15 \mathrm{~m} \mathrm{~s}^{-1}$ ) is found to be similar to that of zonal winds during the entire observation period, indicating that the zonal and meridional winds are strong at $15-17 \mathrm{~km}$. Figure 4 (bottom panel) shows a strong vertical shear greater than $0.02 \mathrm{~s}^{-1}$ in magnitude, with a maximum of $\pm 0.06 \mathrm{~s}^{-1}$ around $15-17.5 \mathrm{~km}$. The magnitude of vertical wind shear is found to be larger than the Brunt-Vaisala frequency $\left(\sim 0.0070-0.0209 \mathrm{~s}^{-1}\right)$ in the upper troposphere and lower stratospheric (UTLS) regions. This indicates, as in Ramkumar et al. (2010), that the unstable shear layers (Fig. 4) were the important sources for the generation of GWs.

\subsection{Convective gravity wave characteristics}

In order to define the stages of convection we consider convective activity, minimum subcloud buoyancy and minimum value of tropospheric vertical velocity at a given time. Convective activity and minimum sub-cloud buoyancy were defined, following Beres et al. (2002), as:

Convective activity (CA) as a function of time $t$ :

$\mathrm{CA}(t)=w_{\max }^{2}(t)\left(\mathrm{m}^{2} \mathrm{~s}^{-2}\right)$,

where $w_{\max }$ is the maximum value of tropospheric vertical velocity at a given time.

Minimum subcloud buoyancy $B_{\min }$ as a function of time, $t$ :

$B_{\min }(t)=\min \left(\frac{\theta-\bar{\theta}(z)}{\theta_{0}} g\right)\left(\mathrm{m} \mathrm{s}^{-2}\right)$,

where $\min ()$ refers to a value in the domain at a given time $t$. $B_{\text {min }}$ represents the strength of the cold pool and $\theta$ is the air mass, given by:

$\theta=T\left(\frac{p_{0}}{p}\right)^{\kappa}(\mathrm{K})$,

where $T, p$ are temperature and pressure and $p_{0}=1000 \mathrm{hPa}$. This is calculated from ERA. The reason is that the temperature data from ERA have a bias of nearly $\pm 2 \mathrm{~K}$, with the GPS radiosonde observations available since August 2006 at GDK.

1. Initial phase: during Event 1, the storm consists of a single convective cell with strong central updraft. At 


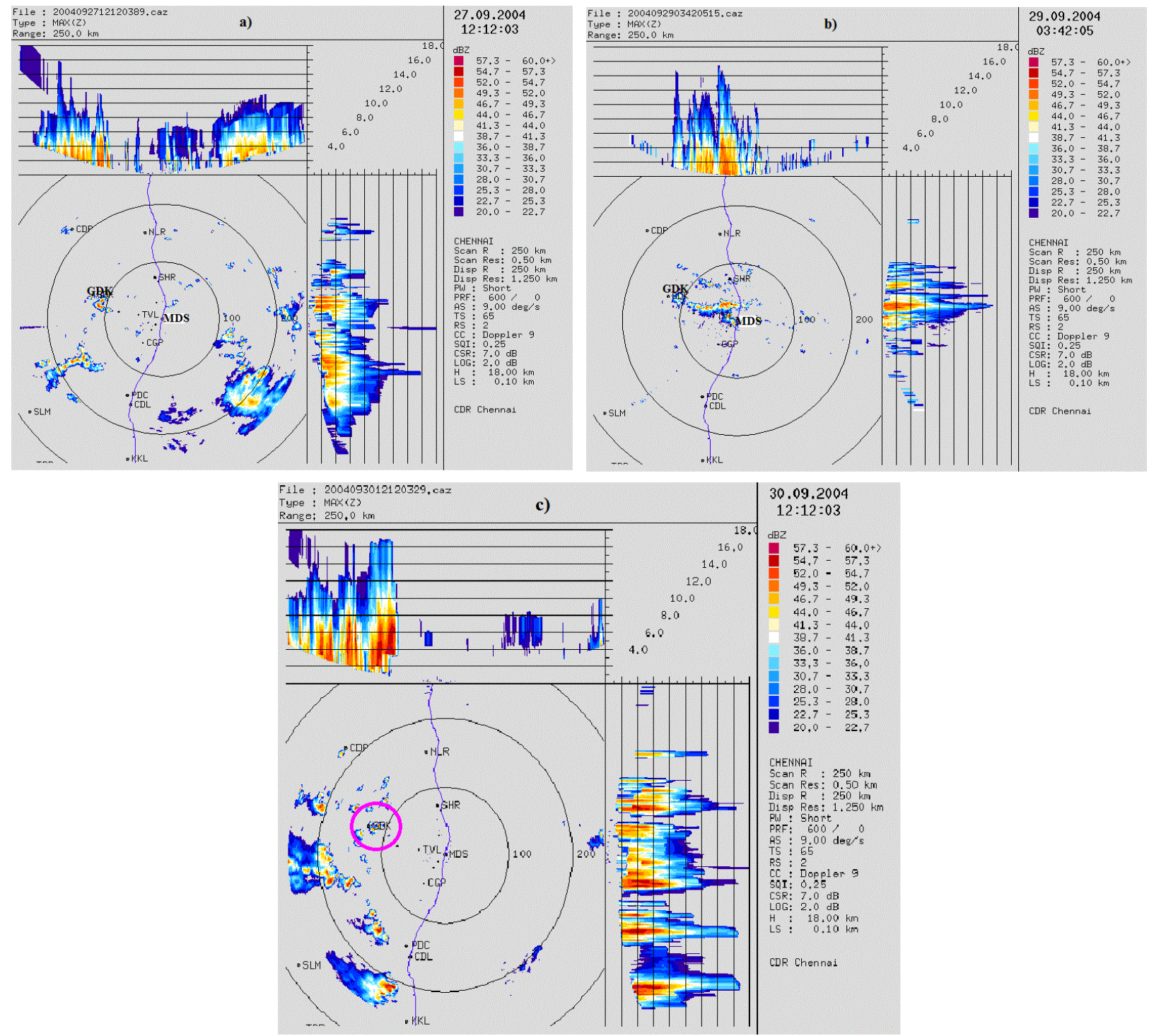

Fig. 2. Doppler Weather Radar images from Chennai on (a) 27 September 2004 at 17:42:03 LT, (b) 29 September 2004 at 09:12:05 LT and (c) 30 September 2004 at 17:42:03 LT, corresponding to events I and II, respectively.

this stage the magnitudes of the vertical updrafts and downdrafts are $2.64 \mathrm{~m} \mathrm{~s}^{-1}$ and $4.19 \mathrm{~m} \mathrm{~s}^{-1}$ (Fig. 5a and b), respectively. The surface cold pool is strong during this period, because of the low values of minimum subcloud buoyancy $\left(-1.06 \mathrm{~m} \mathrm{~s}^{-2}\right)$ as in Fig. $5 \mathrm{c}$.

2. Mature phase: during Event 2 (at 09:00 LT), a squall line consisting of many convective cells moved in a westward direction from the MDS coast towards the GDK region (as reported by the Doppler Weather Radar (DWR) observation, IMD, Chennai). Although the $B_{\min }$ for both the events are almost the same, updrafts $\left(4.21 \mathrm{~m} \mathrm{~s}^{-1}\right.$ and $\left.4.44 \mathrm{~m} \mathrm{~s}^{-1}\right)$ are weaker than downdrafts $\left(6.46 \mathrm{~m} \mathrm{~s}^{-1}\right.$ and $\left.4.69 \mathrm{~m} \mathrm{~s}^{-1}\right)$ in both cases.
3. Dissipation phase: it is observed that the magnitude of maximum updrafts is weakened further $\left(1.63 \mathrm{~m} \mathrm{~s}^{-1}\right)$ compared with downdrafts $\left(3.84 \mathrm{~m} \mathrm{~s}^{-1}\right)$ for Event 1 (at 18:30 LT), and the corresponding values are $1.32 \mathrm{~m} \mathrm{~s}^{-1}$ and $3.56 \mathrm{~m} \mathrm{~s}^{-1}$ for Event 2 (at 10:00 LT), respectively, during this stage.

\subsubsection{Wavelet analysis}

CWT analysis is applied to localize the main modes of oscillation in restricted intervals of the data series (de la Torre et al., 2012; Hierro et al., 2012). In order to observe dominant spectral components in vertical wind perturbations, a Morlet (mother wavelet) continuous wavelet transform (CWT) (Torrence and Compo, 1998) is employed. Because 


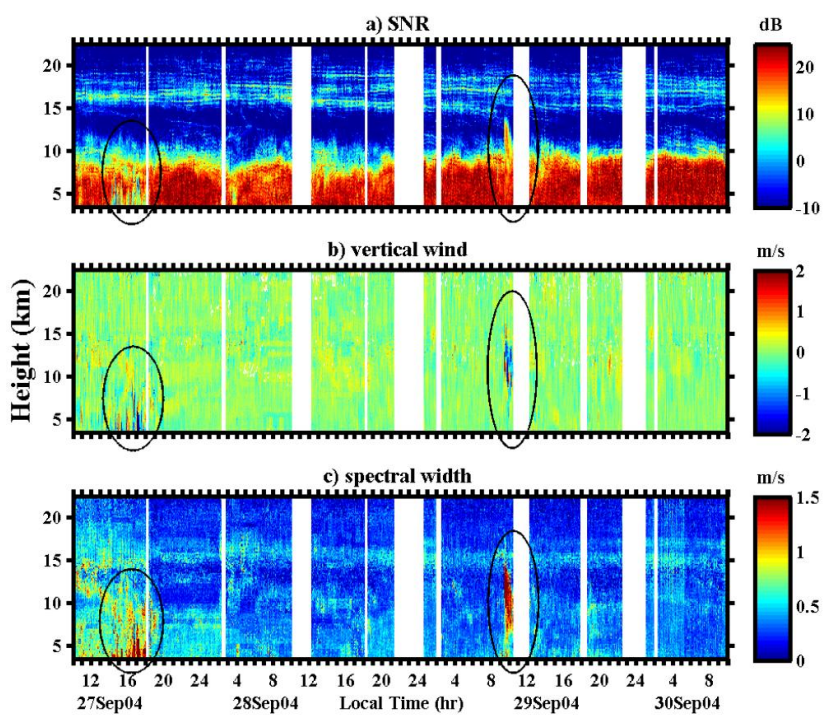

Fig. 3. Height-time section of (a) SNR, (b) vertical wind velocity $\left(\mathrm{m} \mathrm{s}^{-1}\right)$ and (c) spectral width $\left(\mathrm{m} \mathrm{s}^{-1}\right)$ derived from the vertically pointed radar beam $\left(Z_{x}\right)$ for 27-30 September 2004, and the demarcated areas inside circles and ellipses correspond to thunderstorm and squall line passages over Gadanki.

of refraction effects and the intense background wind shear in the UTLS region, the amplitude of the CGW may not be the same throughout the UTLS region. In order to determine the dominant modes of oscillation, the UTLS region is divided into three parts, namely the mid-tropospere (MT), upper troposphere (UT) and lower stratosphere (LS). Since the sources of short GWs are most likely found in the middle and upper tropospheres, their propagation direction is mostly upward. We apply the CWT analysis to the perturbed vertical velocity (as in Alexander et al., 2008; Schmidt et al., 2008; Llamedo et al., 2009; de la Torre et al., 2011, 2012; Hierro et al., 2012) to obtain the dominant modes between $4 \mathrm{~min}$ and $120 \mathrm{~min}$. In order to distinguish the CGWs from other oscillations such as GWs, which are generated by turbulent wind shear and buoyancy oscillations, the data are classified into three parts. They are (a) before convection, (b) during convection and (c) after convection (Fig. 6a, b and c, respectively). Time history of peak vertical velocities (only during convection) is obtained taking the average over a given height region, and corresponding periodicities are tabulated for both the events I and II in Table 1a.

\section{Before convection (12:30 LT to 14:30 LT on 27 September and 05:00 LT to 07:00 LT on 29 September)}

Before convective Event 1 the wave periods are found to be 20-32 min and 16-48 $\mathrm{min}$ in the MT, 16-32 min and 40$60 \mathrm{~min}$ in the UT and $4-8 \mathrm{~min}$ in the LS regions. There are $20-40 \mathrm{~min}$ and $40-80 \mathrm{~min}$ periodicities in the MT, 8$16 \mathrm{~min}, 20-40 \mathrm{~min}$ and $40-80 \mathrm{~min}$ periodicities in the UT,

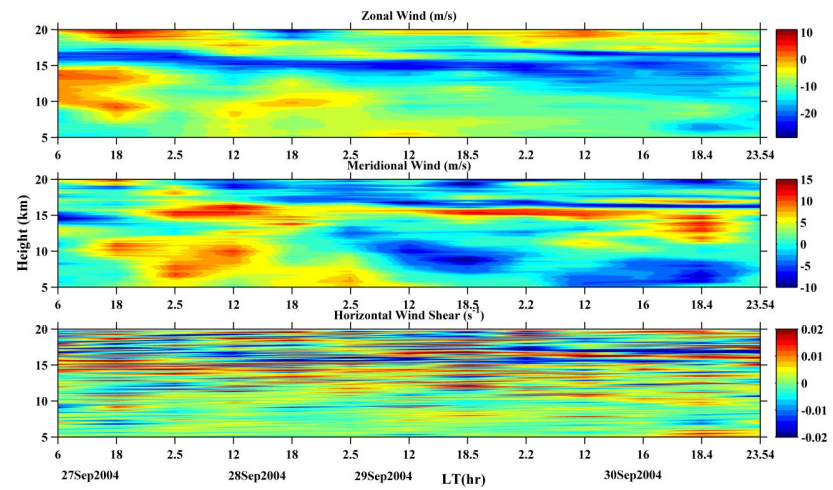

Fig. 4. Height-time section of background zonal wind $\left(\mathrm{m} \mathrm{s}^{-1}\right)$ (top), meridional $\left(\mathrm{m} \mathrm{s}^{-1}\right)$ wind (middle) and corresponding horizontal wind shear ( $\mathrm{s}^{-1}$ ) (bottom) for 27-30 September 2004.

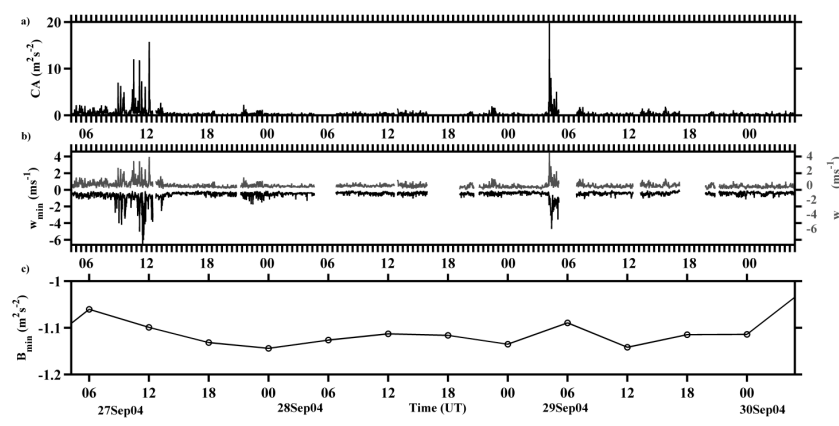

Fig. 5. (a) Plot of convective activity (CA) $\left(\mathrm{m}^{2} \mathrm{~s}^{-2}\right)$, (b) vertical velocity $\left(\mathrm{m} \mathrm{s}^{-1}\right)$ in downward $\left(w_{\min }\right.$, black) and upward ( $w_{\max }$, gray) direction during the radar observation and (c) minimum sub-cloud buoyancy $\left(B_{\min }\right)\left(\mathrm{m} \mathrm{s}^{-2}\right)$ calculated using ERA-Interim temperature profiles for 27-30 September 2004. (Note: $\mathrm{LT}=\mathrm{UT}+5.5 \mathrm{~h}$ )

and 4-8 min periodicities in the LS regions are found to be dominant before the squall-line Event 2 .

\section{During convection (14:30 LT to 18:18 LT on 27 September and 07:00 LT to 10:35 LT on 29 September)}

During the initial stage of Event 1, the periodicities are found to be $10-20 \mathrm{~min}, 24-32 \mathrm{~min}$ and $48-96 \mathrm{~min}$ in the MT region, 16-20 $\mathrm{min}$ and 48-96 $\mathrm{min}$ in the UT region and 4-8 min and $20-40 \mathrm{~min}$ in the LS region. In mature stage, the periodicities are found to be 4-8 $\mathrm{min}, 10-20 \mathrm{~min}, 24-48 \mathrm{~min}$ and $52-$ $96 \mathrm{~min}$ in the MT, $16-32 \mathrm{~min}, 32-48 \mathrm{~min}$ and $52-96 \mathrm{~min}$ in the UT and 4-8 $\min$ in the LS regions, whereas during the mature stage of Event 2, the periodicities are 8-20 min, 16$32 \mathrm{~min}$ and 32-96 $\mathrm{min}$ in MT, 4-24 $\mathrm{min}$ and 16-96 $\mathrm{min}$ in the UT and 4-8 $\mathrm{min}, 6-12 \mathrm{~min}$ and $16-28 \mathrm{~min}$ in the LS regions. 
Table 1. (a) The vertical wavelengths of temperature, zonal and meridional wind perturbations calculated using a fast Fourier transform at various heights.

\begin{tabular}{llllll}
\hline \multicolumn{7}{l}{ (a) Gravity wave periodicities from wavelet analysis } & \\
\hline S. & & \multicolumn{2}{c}{ 27 Sep 2004 } & \multicolumn{2}{c}{ 29 Sep 2004 } \\
No. & Region of interest & Initial & Mature & Initial & Mature \\
\hline 1. & MT region (in min) & $16 ; 32 ; 80$ & $24 ; 32$ & - & $16 ; 24 ; 80$ \\
2. & UT region (in min) & $16 ; 80$ & $10 ; 32 ; 80$ & - & $16 ; 48$ \\
3. & LS region (in min) & $8 ; 32$ & 8 & - & 10
\end{tabular}
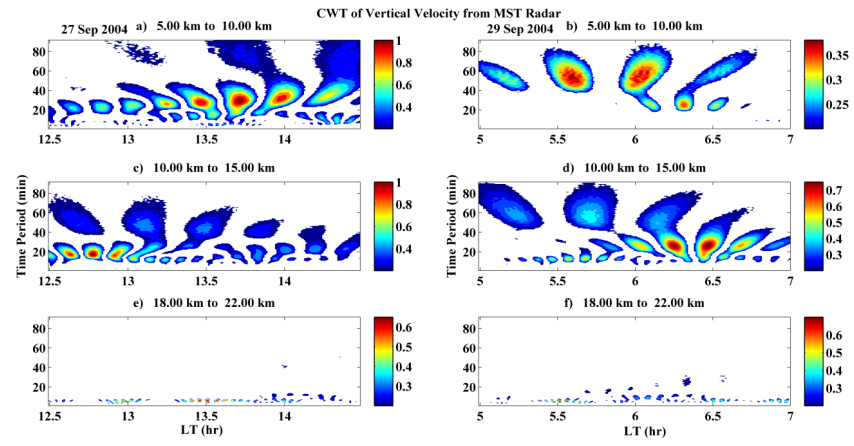

Fig. 6a. CWT of vertical wind velocities $\left(\mathrm{m} \mathrm{s}^{-1}\right)$ before convection in the height regions 5-10 km (a and d), 10-15 km (b and e) and 18$22 \mathrm{~km}$ (c and f) for 27 September 2004 (left panel) and 29 September 2004 (right panel), respectively.

\section{After convection (22:30 LT to 24:30 LT on 27 September and 13:00 LT to 15:00 LT on 29 September)}

The wave periods are found to be $48-96 \mathrm{~min}$ in the MT, 4$8 \mathrm{~min}$ in the UT and 4-6 $\mathrm{min}$ in the LS region, dominant after the convective Event 1 . There are also $8-16 \mathrm{~min}$ and $32-$ 64 min periodicities in the MT, 4-8 min and $20-52$ min periodicities in the UT, and 4-8 $\mathrm{min}$ and $24-48 \mathrm{~min}$ in the LS regions are found to be dominant after the squall-line Event 2 .

\subsubsection{Hodograph analysis}

Hodograph analysis is carried out to determine the GW vertical wavelength and horizontal direction of propagation following Tsuda et al. (1990). Hodographs were obtained following Dutta et al. (2009) along the direction of propagation, both in the troposphere $(4-15 \mathrm{~km})$ and lower stratosphere (15-22 km) on 27 and 29 September 2004,1 or $2 \mathrm{~h}$ after the end of convection along the direction of propagation. These are illustrated in Figs. 7 and 8, and their corresponding vertical wavelengths (representing a complete rotation of hodographs) are tabulated in Table 1c.

From Figs. 7 and 8, the hodographs show counterclockwise and clockwise rotation, in the troposphere (source region) and stratosphere, respectively, leading to upward energy propagation. As the upward and downward energy

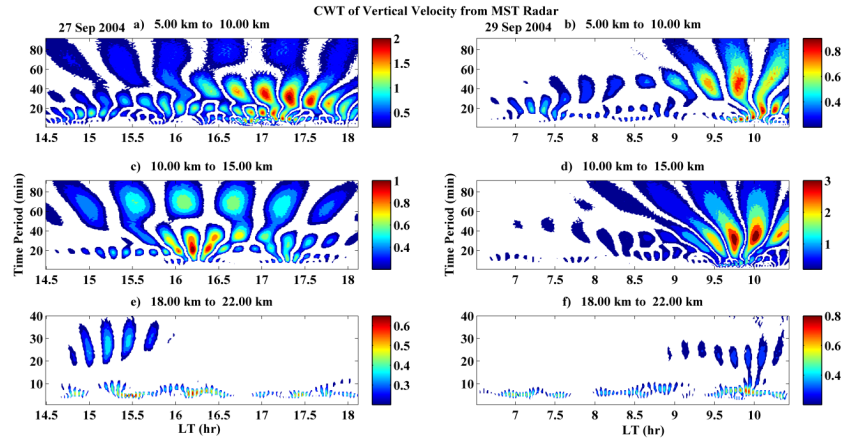

Fig. 6b. Same as Fig. 6a during convection.

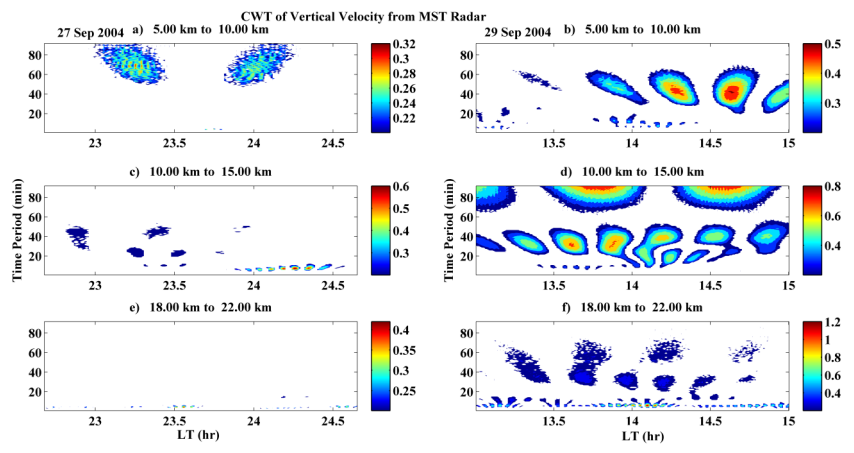

Fig. 6c. Same as Fig. 6a and b after convection.

propagation found, its source could be present between the two regions, i.e., the strong shear zones near the tropopause. Strong wind shear (Fig. 4) associated with convection may generate GWs near the tropopause that may influence the structure of CGWs, leading to the formation of complicated wave structures (Vekat Ratnam et al., 2008). In this case it is difficult to distinguish the CGWs from shear-generated GWs. The horizontal direction of propagation of GWs as revealed from Fig. 7 is NNE-NE on 27 September 2004 and is NE-E on 29 September 2004, respectively. It could be mentioned that the direction of propagation of GWs coincides with the direction of movement of storm. Dutta et al. (2009), in their study on characteristics of short-period GWs, made a similar analysis in order to find the energy direction of propagation and found that the directions inferred from hodograph 
Table 1. (b) Vertical wavelengths estimated using hodograph analysis and (c) significant gravity wave periodicities noticed from the wavelet amplitude spectrum of perturbation of vertical wind velocity from MST radar in the middle troposphere (MT), upper troposphere (UT) and lower stratospheric (LS) regions during the thunderstorm and squall line passage over Gadanki.

(b) Vertical wavelengths from vertical wavenumber spectra of gravity waves

\begin{tabular}{|c|c|c|c|c|c|c|c|}
\hline \multirow{2}{*}{$\begin{array}{l}\text { S. } \\
\text { no. }\end{array}$} & \multirow{2}{*}{$\begin{array}{l}\text { Vertical } \\
\text { wavelength }\end{array}$} & \multicolumn{3}{|c|}{27 Sep 2004} & \multicolumn{3}{|c|}{29 Sep 2004} \\
\hline & & Initial & Mature & Dissipative & Initial & Mature & Dissipative \\
\hline 1. & $\mathrm{~T}$ region $(\mathrm{km})$ & $3.2 ; 4.8$ & $3.84 ; 6.4$ & $3.2 ; 4.8$ & - & 3.84 & 3.2 \\
\hline 2. & LS region $(\mathrm{km})$ & 1.6 & $1.92 ; 3.2$ & 1.92 & - & 1.371 & 1.2 \\
\hline
\end{tabular}

(c) Vertical wavelengths from hodograph analysis

\begin{tabular}{lllll}
\hline & \multicolumn{2}{c}{ Troposphere } & \multicolumn{2}{c}{ Stratosphere } \\
& 27 Sep 2004 & 29 Sep 2004 & 27 Sep 2004 & 29 Sep 2004 \\
\hline Time (LT) & $18: 18$ & $12: 00$ & $18: 18$ & $12: 00$ \\
$\lambda_{z}(\mathrm{~km})$ & 3.70 & 4.00 & 1.48 & 2.08 \\
\hline
\end{tabular}

analyses are not conclusive. They also found that interaction between CGWs and shear-generated waves (low-frequency waves) could lead to the formation of nonlinear wave structures, it being difficult to distinguish them. This could be one of the reasons for the rotation of hodographs in violating the linear theory of GWs. The other reason would be the geographical variation of the wave packet due to large-scale convective movement in the background (Zhang et al., 2004).

\subsubsection{Phase profiles}

To find the direction of vertical propagation we computed the phase profiles of gravity wave corresponding to the dominant period for both events 1 and 2 using a fast Fourier transform (FFT) analysis as shown in Fig. 9. It is very interesting to note that these profiles show both downward and upward wave propagation during Event 1 and only upward propagation during Event 2. The phase profile of Event 1 shows that there are regions with reasonably constant phases, one at $10-11 \mathrm{~km}$ and another at $13.5-15 \mathrm{~km}$ within the troposphere. The phase profile of Event 2 shows that the waves propagate upward above $14 \mathrm{~km}$, downward below $10 \mathrm{~km}$, and that the phase is nearly constant in the $10.5-13.5 \mathrm{~km}$ region. The downward propagation of waves is due to the existence of strong shear zones near the tropopause at which partial reflection of waves may take place. The upward propagation is due to the existence of strong vertical updrafts associated with convection as in Kumar (2006).

\subsubsection{Vertical wavenumber spectrum}

Vertical wavenumber spectra are computed from the fluctuation profiles of vertical velocities by removing background mean from the profiles. Then, the corresponding height profiles are subjected to FFT analysis. Figure 10 reveals the vertical wavenumber spectra of winds for initial, mature and dissipative phases of convection (of tropospheric $(4-15 \mathrm{~km})$ and lower stratospheric $(17-22.5 \mathrm{~km})$
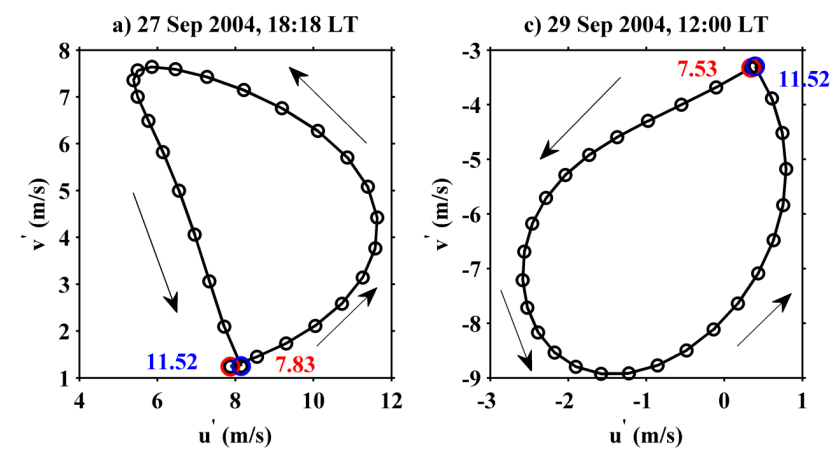

b) 27 Sep 2004:7.83 km-11.52 km

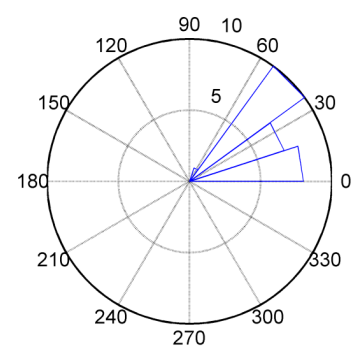

d) 29 Sep 2004:7.53 km-11.52 km

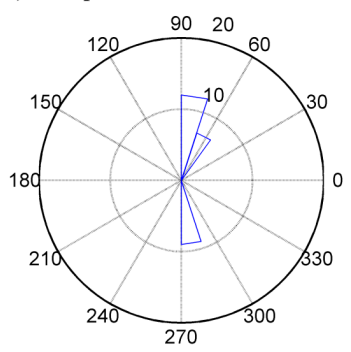

Fig. 7. Hodographs of wind fluctuations (a and $\mathbf{c}$ ) with arrows indicating direction of rotation and corresponding horizontal direction of propagation (b and $\mathbf{d}$ ) of the gravity waves. They are plotted for every $30^{\circ}$ of 27 September 2004 and 29 September 2004 after about $1 \mathrm{~h}$ of cessation of convection in the tropospheric region $(4-15 \mathrm{~km})$. Values $0^{\circ}, 90^{\circ}, 180^{\circ}$, and $270^{\circ}$ are assigned as the eastward, northward, westward, and southward directions, respectively.

segments) for 27 September 2004 16:30 LT (black), 17:30 LT (black dashed) and 18:30 LT (gray) and mature and dissipative phases of convection for 29 September 2004 09:00 LT (black) and 10:00 LT (gray). Vertical wavelengths of GWs are tabulated for different phases of convection in Table $1 \mathrm{~b}$. The spectral slopes of vertical velocity fluctuations $\left(w^{\prime}\right)$ in the troposphere are found to be -1.8 (initial); -2.5 (mature) 


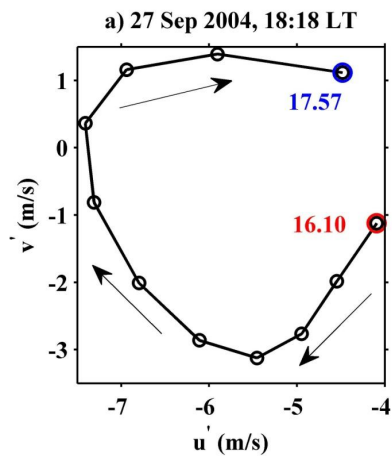

b) $27 \operatorname{Sep} 2004: 16.10 \mathrm{~km}-17.57 \mathrm{~km}$

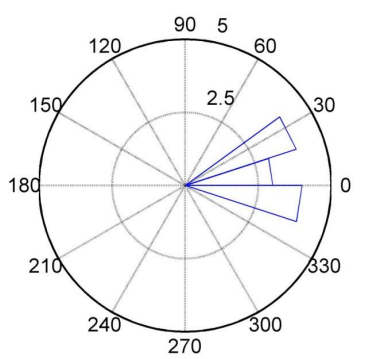

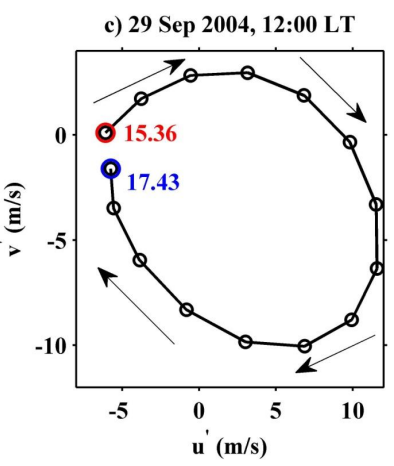

d) 29 Sep 2004:15.36 km-17.43 km

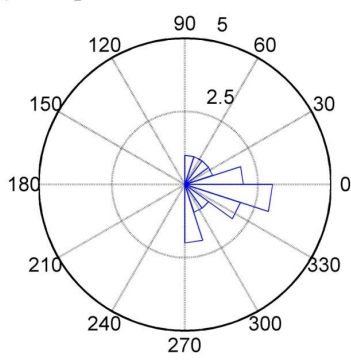

Fig. 8. Same as Fig. 6 for the lower stratospheric region $(15-22 \mathrm{~km})$.

and -1.8 (dissipative) for Event 1 and -1.75 (mature) and -1.85 (dissipative) for Event 2. The slopes in the stratosphere are found to be -1.15 (initial); -1.5 (mature) and -1.5 (dissipative) for Event 1 and -1.6 (mature); -1.6 (dissipative) for Event 2.

\subsubsection{Estimation of gravity wave parameters from dispersion relation}

We now illustrate the wave parameters using linear wave theory (Eqs. 3-6) (Dewan et al., 1998; Dhaka et al., 2003; Sentman et al., 2003) during the initial and mature phases of convection for Event 1 and only during the mature phase of convection Event 2 (since the squall line reached GDK in its matured stage):

Dispersion relation : $\omega^{2}=\frac{N^{2} k^{2}}{m^{2}+k^{2}}$

Intrinsic group velocity : $c_{g x}=\partial \omega / \partial k_{x}$

$$
\begin{aligned}
& =\left(\lambda_{x} / \tau\right)\left\{1-\left(\tau_{B} / \tau\right)^{2}\right\} \text { and } \\
c_{g z} & =\partial \omega / \partial k=\left(\lambda_{z} / \tau\right) \cos ^{2} \varphi
\end{aligned}
$$

Horizontal direction of propagation :

$\varphi=c_{g z} / c_{g x}=k / m=\lambda_{z} / \lambda_{x}$ or

$\tan \varphi=\left\{\left(\tau / \tau_{B}\right)^{2}-1\right\}^{-1 / 2}$

Intrinsic phase velocity : $c_{p x}=\omega / k_{x}$ and $c_{p z}=\omega / k_{z}$,

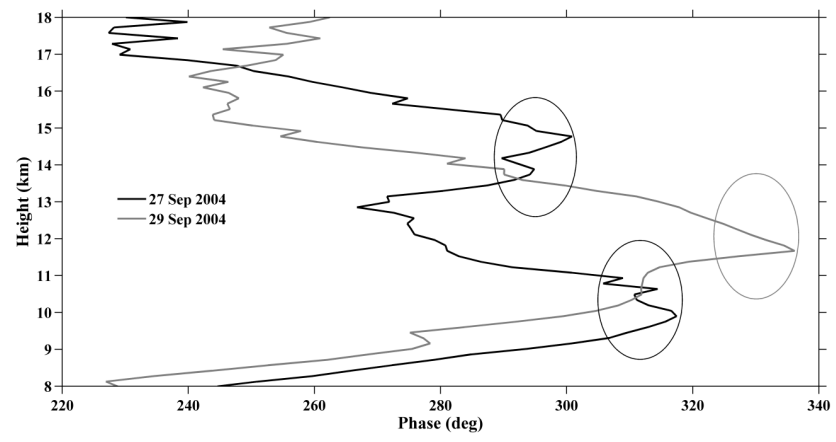

Fig. 9. Phase profile of dominant wave periods for events 1 and 2.

where $\omega$ : intrinsic frequency, $N$ : Brunt-Väisälä frequency, $m$ : vertical wave number, $k$ : horizontal wave number, $\varphi$ : elevation angle of group velocity vector, $\tau$ : wave period, $\tau_{B}$ : Brunt-Väisälä period, $\lambda_{x}$ : horizontal wavelength, $\lambda_{z}$ : vertical wavelength; $c_{g x}, c_{g z}, c_{p x}$ and $c_{p z}$ are: components of intrinsic group velocity and phase velocity, respectively. The gravity wave parameters from Eqs. (1)-(4) are given in tables 2 and 3 for events 1 and 2 in both tropospheric and stratospheric regions. The gravity wave parameters are found to be different from Event 1 to 2 and also from initial to mature phase. From tables 2 and 3 , it can be noticed that $\lambda_{x}$ is a linear function of $\lambda_{z}$ and $\tau$. The horizontal group and phase velocities $\left(c_{g x}\right.$ and $\left.c_{p x}\right)$ increase with an increase in periodicity $(\tau)$ of the wave as well as the horizontal wavelength $\left(\lambda_{x}\right)$, and which is converse.

From the present (tables 2 and 3) short-period GW observations, those with periodicities $32 \mathrm{~min}$ and $80 \mathrm{~min}$ during Event 1 and $48 \mathrm{~min}$ and $80 \mathrm{~min}$ during Event 2 are found to be dominant for vertical propagation. The GWs with periodicities (namely, $8 \mathrm{~min}, 10 \mathrm{~min}, 16 \mathrm{~min}$ and $24 \mathrm{~min}$ on 27 September and 29 September 2004) and weak amplitudes are removed by critical level filtering due to the influence of strong horizontal wind shear associated with convection (as in Preusse et al., 2008).

\subsection{Gravity wave generation mechanisms}

Strong convective updrafts are commonly associated with the release of a significant amount of latent heat by the convective system. In the present study, the convective events associated with upward propagating GWs lead to enhanced echo power, thereby increasing SNR (Fig. 3). It is clear from the vertical wavenumber spectra and hodograph analysis that vertical wavelengths in the stratosphere are close to half of those estimated in the troposphere in both the events (Table $1 b$ and c). As is evident from Salby and Garcia (1987), McLandress et al. (2000) and Beres et al. (2002), in the present GW events may be generated by the thermal forcing due to diabatic heating.

However, during the passage of squall line there is strong convective overshooting (as the storm is reached over GDK 
Table 2a. Gravity wave dispersion parameters for 27 September 2004 in the troposphere.

\begin{tabular}{|c|c|c|c|c|c|c|c|c|}
\hline \multicolumn{9}{|c|}{27 September 2004} \\
\hline \multirow{3}{*}{$\lambda_{z}(\mathrm{~km})$} & \multicolumn{3}{|c|}{ Initial Phase } & & \multicolumn{4}{|c|}{ Mature Phase } \\
\hline & \multirow[t]{2}{*}{ GW Parameters } & \multicolumn{2}{|c|}{$\begin{array}{l}\text { Troposphere } \\
\tau \text { (min) }\end{array}$} & \multirow[t]{2}{*}{$\lambda_{z}(\mathrm{~km})$} & \multirow[t]{2}{*}{ GW Parameters } & \multicolumn{3}{|c|}{$\begin{array}{c}\text { Troposphere } \\
\tau \text { (min) }\end{array}$} \\
\hline & & 16 & 80 & & & 10 & 24 & 32 \\
\hline \multirow[t]{6}{*}{3.2} & $\lambda_{h}(\mathrm{~km})$ & 4.37 & 26.92 & \multirow[t]{6}{*}{3.84} & $\lambda_{h}(\mathrm{~km})$ & 1.33 & 8.97 & 12.33 \\
\hline & $c_{g x}\left(\mathrm{~m} \mathrm{~s}^{-1}\right)$ & 2.97 & 5.53 & & $c_{g x}\left(\mathrm{~m} \mathrm{~s}^{-1}\right)$ & 0.24 & 5.24 & 5.91 \\
\hline & $c_{g z}\left(\mathrm{~m} \mathrm{~s}^{-1}\right)$ & 2.17 & 0.65 & & $c_{g z}\left(\mathrm{~m} \mathrm{~s}^{-1}\right)$ & 0.69 & 2.251 .82 & \\
\hline & $c_{p x}\left(\mathrm{~m} \mathrm{~s}^{-1}\right)$ & 4.56 & 5.60 & & $c_{p x}\left(\mathrm{~m} \mathrm{~s}^{-1}\right)$ & 2.23 & 6.23 & 6.47 \\
\hline & $c_{p z}\left(\mathrm{~m} \mathrm{~s}^{-1}\right)$ & 3.33 & 0.66 & & $c_{p z}\left(\mathrm{~ms}^{-1}\right)$ & 6.40 & 2.67 & 2.00 \\
\hline & $\phi(\mathrm{deg})$ & 41.88 & 6.80 & & $\phi(\mathrm{deg})$ & 164.2 & 24.51 & 17.69 \\
\hline \multirow[t]{6}{*}{4.8} & $\lambda_{h}(\mathrm{~km})$ & 6.56 & 40.38 & \multirow[t]{6}{*}{6.4} & $\lambda_{h}(\mathrm{~km})$ & 2.23 & 14.95 & 20.72 \\
\hline & $c_{g x}\left(\mathrm{~m} \mathrm{~s}^{-1}\right)$ & 4.45 & 8.29 & & $c_{g x}\left(\mathrm{~m} \mathrm{~s}^{-1}\right)$ & 0.40 & 8.77 & 9.85 \\
\hline & $c_{g z}\left(\mathrm{~m} \mathrm{~s}^{-1}\right)$ & 3.25 & 0.98 & & $c_{g z}\left(\mathrm{~m} \mathrm{~s}^{-1}\right)$ & 1.15 & 3.75 & 3.04 \\
\hline & $c_{p x}\left(\mathrm{~m} \mathrm{~s}^{-1}\right)$ & 6.84 & 8.41 & & $c_{p x}\left(\mathrm{~m} \mathrm{~s}^{-1}\right)$ & 3.72 & 10.38 & 10.79 \\
\hline & $c_{p z}\left(\mathrm{~m} \mathrm{~s}^{-1}\right)$ & 5 & 1 & & $c_{p z}\left(\mathrm{~m} \mathrm{~s}^{-1}\right)$ & 10.67 & 4.44 & 3.33 \\
\hline & $\phi(\mathrm{deg})$ & 41.88 & 6.80 & & $\phi(\mathrm{deg})$ & 164.2 & 24.51 & 17.69 \\
\hline
\end{tabular}

Table 2b. Same as Table 2a in the stratosphere.

\begin{tabular}{rlrrrrr}
\hline & & \multicolumn{3}{c}{ Stratosphere } & & Stratosphere \\
& & & & \\
& & & & \\
& & 8 & 32 & & \\
& & & & & \\
\hline 1.6 & $\lambda_{h}(\mathrm{~km})$ & 2.06 & 10.33 & $1.92,3.2$ & $\lambda_{h}(\mathrm{~km})$ & $2.48,4.14$ \\
& $c_{g x}\left(\mathrm{~m} \mathrm{~s}^{-1}\right)$ & 1.39 & 2.72 & & $c_{g x}\left(\mathrm{~m} \mathrm{~s}^{-1}\right)$ & $1.67,2.79$ \\
& $c_{g z}\left(\mathrm{~m} \mathrm{~s}^{-1}\right)$ & 1.08 & 0.42 & & $c_{g z}\left(\mathrm{~m} \mathrm{~s}^{-1}\right)$ & $1.29,2.16$ \\
& $c_{p x}\left(\mathrm{~m} \mathrm{~s}^{-1}\right)$ & 4.31 & 5.38 & & $c_{p x}\left(\mathrm{~m} \mathrm{~s}^{-1}\right)$ & $5.17,8.62$ \\
& $c_{p z}\left(\mathrm{~m} \mathrm{~s}^{-1}\right)$ & 3.33 & 0.83 & & $c_{p z}\left(\mathrm{~m} \mathrm{~s}^{-1}\right)$ & $4.00,6.67$ \\
$\phi(\operatorname{deg})$ & 44.30 & 8.86 & & $\phi(\mathrm{deg})$ & $44.33,44.33$ \\
\hline
\end{tabular}

in its mature stage) associated with strong vertical updrafts and downdrafts, which can be easily noticed from SNR and spectral width (Fig. 3, encircled with ellipses). There was relatively strong shear $\left(\sim 0.06 \mathrm{~s}^{-1}\right.$, Fig. 4$)$ associated with the squall-line passage and it acted as an obstacle to non-zero background wind ( $\sim 25-28 \mathrm{~m} \mathrm{~s}^{-1}$ near tropopause). This led to the generation of GWs, even above clouds, the obstacle effect being the apparent prominent mechanism. Similar features were observed in the case of squall-line simulation of vertical shear of horizontal wind by Beres et al. (2002). The obstacle effect is not present when the wind shear layer is located strictly far above the heating region (during Event 1 , Figs. 4 and 9) rather than near the top and above it (Lane and Reeder, 2001).

Wavelet amplitude spectra for the different time intervals showed short-period ( $\sim 10 \mathrm{~min}$ to $80 \mathrm{~min}$ ) oscillations during events 1 and 2, as explained in Sect. 3.2.1. Table 1a shows that there are harmonics of $16 \mathrm{~min}, 24 \mathrm{~min}, 32 \mathrm{~min}$ and $80 \mathrm{~min}$ in the MT region; $10 \mathrm{~min}, 16 \mathrm{~min}, 32 \mathrm{~min}$ and
$80 \mathrm{~min}$ in the UT region; and $8 \mathrm{~min}$ and $32 \mathrm{~min}$ in the LS region during thunderstorm events. Similarly, $16 \mathrm{~min}, 24 \mathrm{~min}$ and $80 \mathrm{~min}$ in the MT region; $16 \mathrm{~min}$ and $48 \mathrm{~min}$ in the UT region; and $10 \mathrm{~min}$ in the LS region during squall-line events. If the mechanical oscillator mechanism is effective, one should notice the harmonics in the stratosphere similar to that of tropospheric oscillations, which is true for the present observation of CGWs. The results obtained from the current observational study reconfirm that the mechanical oscillator effect is also effective in generating the GWs, as reported in earlier studies (Lane and Reeder, 2001; Dhaka et al., 2002, 2003; Beres et al., 2004; Kumar, 2006, 2007; Dutta et al., 2009).

\section{Summary and concluding remarks}

In this paper, from Indian MST radar data, an attempt to explain the convectively generated gravity wave propagation characteristics in initial, mature and dissipation stages of convection during the passage of thunderstorm and squall 
Table 3. Same as Table 2 for 29 September 2004.

\begin{tabular}{|c|c|c|c|c|c|c|c|c|}
\hline \multicolumn{9}{|c|}{29 September 2004 (Mature Phase) } \\
\hline \multirow[b]{2}{*}{$\lambda_{z}(\mathrm{~km})$} & & \multicolumn{3}{|c|}{$\begin{array}{c}\text { Troposphere } \\
\tau \text { (min) }\end{array}$} & \multirow[b]{2}{*}{80} & \multirow[b]{2}{*}{$\lambda_{z}(\mathrm{~km})$} & & \multirow{2}{*}{$\begin{array}{r}\text { Stratosphere } \\
\tau \text { (min) } \\
10\end{array}$} \\
\hline & & 16 & 24 & 48 & & & & \\
\hline \multirow[t]{6}{*}{1.6} & $\lambda_{h}(\mathrm{~km})$ & 5.25 & 8.97 & 19.14 & 32.30 & 1.37 & $\lambda_{h}(\mathrm{~km})$ & 2.44 \\
\hline & $c_{g x}\left(\mathrm{~m} \mathrm{~s}^{-1}\right)$ & 3.64 & 5.38 & 6.52 & 6.78 & & $c_{g x}\left(\mathrm{~m} \mathrm{~s}^{-1}\right)$ & 1.64 \\
\hline & $c_{g z}\left(\mathrm{~m} \mathrm{~s}^{-1}\right)$ & 2.60 & 2.25 & 1.28 & 0.78 & & $c_{g z}\left(\mathrm{~m} \mathrm{~s}^{-1}\right)$ & 0.92 \\
\hline & $c_{p x}\left(\mathrm{~ms}^{-1}\right)$ & 5.47 & 6.23 & 6.64 & 6.73 & & $c_{p x}\left(\mathrm{~m} \mathrm{~s}^{-1}\right)$ & 4.07 \\
\hline & $c_{p z}\left(\mathrm{~ms}^{-1}\right)$ & 4.00 & 2.67 & 1.33 & 0.80 & & $c_{p z}\left(\mathrm{~m} \mathrm{~s}^{-1}\right)$ & 2.28 \\
\hline & $\phi(\mathrm{deg})$ & 41.88 & 24.51 & 11.41 & 6.80 & & $\phi(\mathrm{deg})$ & 32.14 \\
\hline
\end{tabular}
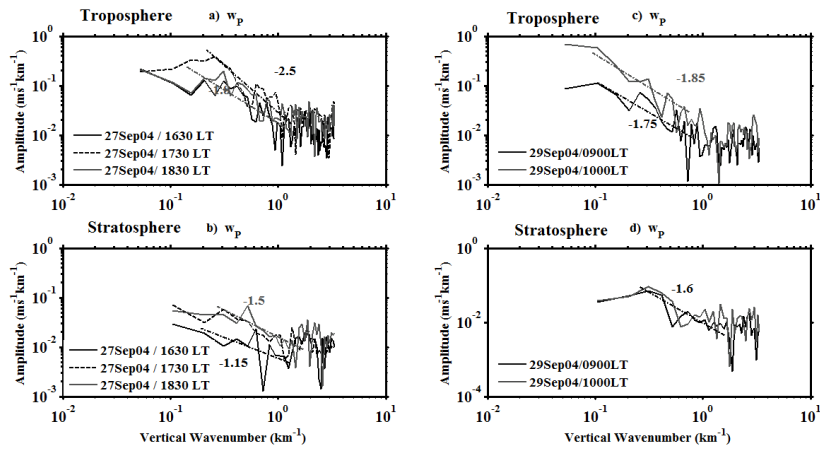

Fig. 10. Vertical wavenumber spectra of gravity waves for the fluctuations of vertical velocity in the troposphere $(4-15 \mathrm{~km})$ (a) for 27 September 2004 at 16:30 LT (black), 17:30 LT (dashed black), 18:30 LT (gray) and (c) for 29 September 2004 at 09:00 LT (black) and 10:00 LT (gray), respectively, and (b and d) for the lower stratospheric region, respectively. The dashed lines in black and gray colors represent the model slope fitting.

line using the continuous observation high-resolution data sets is made. Maximum updrafts and downdrafts are found within the $4-10 \mathrm{~km}$ region during Event 1 and within the $8-16 \mathrm{~km}$ region during Event 2 . From phase profiles and hodograph analysis, it can be noticed that the source might be present within the tropospheric region. Rotation of hodographs is found to be clockwise in the troposphere and anti-clockwise in the lower stratospheric region, and hence, the energy (momentum) transport is upward (downward) of the middle atmosphere. From phase profiles we have also found that there are two regions of constant phase (one at 10$11 \mathrm{~km}$ and the other at $13.5-15 \mathrm{~km}$ within the troposphere) during 27 September 2004. One is due to convective event and the other due to strong background wind shear. However, there is only one constant phase region $(10.5-13.5 \mathrm{~km})$ observed on 29 September 2004 that is only due to a convective process.

Slopes of vertical wavenumber spectra vary between -1.75 and -2.5 in the tropospheric region $(4-15 \mathrm{~km})$ and -1.15 and -1.6 in the stratospheric region. The vertical wavelength $\left(\lambda_{z}\right)$ is found to be maximum for Event 2 compared with Event 1 (Figs. 7, 8 and 10). Also, the vertical wavelengths in the stratosphere are found to be half of those estimated in the troposphere, which is indicative of the vertical extent of heating of the storm (Salby and Garcia, 1987). From tables 2 and 3, it is found that for short-period CGWs the vertical component of group and phase velocities would be maximum and the horizontal component of group and phase velocities would be minimum. Also, the horizontal wavelengths are found to be shorter in the stratosphere, leading to weak horizontal group and phase velocities. Hence we may state that the waves most probably propagate in the vertical direction rather than in the horizontal direction.

The present observation of short-period GWs shows that the waves generated in the troposphere propagate up into the stratosphere due to the presence of strong turbulence mixing associated with shear near the tropopause. A distinct feature differentiating between thunderstorm and squall-line events is sudden enhancement in the SNR and spectral width due to convective overshooting during squall-line events. The mechanisms of CGWs associated with the present study are oscillating updrafts and downdrafts like a harmonic oscillator, deep convective cloud associated with strong wind shear acting like an obstacle to the background mean flow, and strong thermal forcing due to deep convective clouds associated with a significant amount of rainfall. It may be stated that GW generation during Event 1 may be partially due to the mechanical oscillator effect as well as thermal forcing. However, in the case of Event 2, GWs are generated by the mechanical oscillator effect and thermal forcing as well as the effect of obstacle mechanism.

Even though there are dominant wave periods in CWT of vertical velocity perturbation before and after convective events, they are not in agreement with the criteria of the mechanical oscillator effect followed by the earlier authors (Fovell et al., 1992; Lane and Reeder, 2001; Dhaka et al., 2002, 2003; Beres et al., 2004; Kumar, 2006, 2007; Dutta et al., 2009). The tropopause is found to be stable enough before and after convective events, so the GWs with weak amplitudes in the tropospheric region during this period may not 
be able to propagate into the lower stratospheric region. The vertical velocity perturbations amplitude is also weaker and varies between $-0.5 \mathrm{~m} \mathrm{~s}^{-1}$ to $0.5 \mathrm{~m} \mathrm{~s}^{-1}$ before and after convective events. There are GWs present before and after the convective event that may be generated due to the existence of strong turbulence associated with shear but not due to convection. It is important to note that the oscillations of $\sim 8$ $10 \mathrm{~min}$ in the tropical troposphere and of $4.9 \mathrm{~min}$ in the lower stratosphere correspond to the Brunt-Vaisala period. Hence any oscillations greater than these periods are only considered as convectively generated (Dhaka et al., 2003; Kumar, 2007).

Even though the present study reconfirms the earlier results, however, more efforts are needed put forth in differentiating the fractional contributions of these mechanisms in generating GWs during intense convective events with the help of high-resolution, ground-based and satellite-borne observations.

Acknowledgements. The authors are very grateful to the potential reviewers and the editor Copernicus for their valuable comments and suggestions. We are grateful to the Advanced Centre for Atmospheric Sciences (ACAS), sponsored by the Indian Space Research Organization (ISRO) under RESPOND, Sri Venkateswara University, for providing laboratory facilities. Our sincere thanks to the Director, National Atmospheric Research Laboratory (NARL), Gadanki, India Meteorological Department (IMD), Chennai, ECMWF, JMA for providing necessary data and information for this study.

Topical Editor P. M. Ruti thanks two anonymous referees for their help in evaluating this paper.

\section{References}

Alexander, M. J.: The gravity wave response above deep convection in a squall line simulation, J. Atmos. Sci., 52, 2212-2226, 1995.

Alexander, M. J. and Holton, J. R.: A model study of zonal forcing in the equatorial stratosphere by convectively induced gravity waves, J. Atmos. Sci., 54, 408-419, 1997.

Alexander, M. J. and Vincent, R. A.: Gravity waves in the tropical lower stratosphere: A model study of seasonal and interannual variability, J. Geophys. Res., 105, 22299-22310, doi:10.1029/2000JD900196, 2000.

Alexander, S. P., Tsuda, T., and Kawatani, Y.: COSMIC GPS observations of Northern Hemisphere winter stratospheric gravity waves and comparisons with an atmospheric general circulation model, Geophys. Res. Lett., 35, L10808, doi:10.1029/2008GL033174, 2008.

Arkin, P. A. and Meisner, B. N.: The relationship between largescale convective rainfall and cold cloud over the western hemisphere during 1982-1984, Mon. Weather Rev., 115, 51-74, 1987.

Beres, J. H., Alexander, M. J., and Holton, J. R.: Effects of tropospheric wind shear on the spectrum of convectively generated gravity waves, J. Atmos. Sci., 59, 1805-1824, 2002.

Beres, J. H., Alexander, M. J., and Holton, J. R.: A method of specifying the gravity wave spectrum above convection based on la- tent heating properties and background wind, J. Atmos. Sci., 61, 321-337, 2004.

Chen, S. S., Houze Jr., R. A., and Mapes, B. E.: Multiscale variability of deep convection in relation to large-scale circulation in TOGA COARE, J. Atmos. Sci., 53, 1380-1409, 1996.

Clark, T. L., Hauf, T., and Kuettner, J. P.: Convectively forced internal gravity waves: Results from two-dimensional numerical experiments, Q. J. Roy. Meteorol. Soc., 112, 899-925, 1986.

de la Torre, A., Hierro, R., Llamedo, P., Rolla, A., and Alexander, P.: Severe hail storms near southern Andes in the presence of mountain waves, Atmos. Res., 101, 112-123, doi:10.1016/j.atmosres.2011.01.015, 2011.

de la Torre, A., Alexander, P., Hierro, R., Llamedo, P., Rolla, A., Schmidt, T., and Wickert, J.: Large amplitude gravity waves above the Southern Andes, the Drake Passage and the Antarctic Peninsula, J. Geophys. Res., 117, D02106, doi:10.1029/2011JD016377, 2012.

Dewan, E. M., Picard, R. H., O’Neil, R. R., Gardiner, H. A., Gibson, J., Mill, J. D., Richards, E., Kendra, M., and Gallery, W. O.: MSX satellite observations of thunderstorm-generated gravity waves in midwave infrared images of the upper stratosphere, Geophys. Res. Lett., 25, 939-942, 1998.

Dhaka, S. K., Choudhary, R. K., Malik, S., Shibagaki, Y., Yamanaka, M. D., and Fukao, S.: Observable signatures of a convectively generated wave field over the tropics using Indian MST radar at Gadanki $\left(13.5^{\circ} \mathrm{N}, 79.2^{\circ} \mathrm{E}\right)$, Geophys. Res. Lett., 29, 1872, doi:10.1029/2002GL014745, 2002.

Dhaka, S. K., Takahashi, M., Shibagaki, Y., Yamanaka, M. D., and Fukao, S.: Gravity wave generation in the lower stratosphere due to passage of the typhoon 9426 (Orchid) observed by the MU radar at Shigaraki $\left(34.85^{\circ} \mathrm{N}, 136.10^{\circ} \mathrm{E}\right)$, J. Geophys. Res., 108, 4595, doi:10.1029/2003JD003489, 2003.

Dutta, G., Ajay Kumar, M. C., Vinay Kumar, P., Venkat Ratnam, M., Chandrashekar, M., Shibagaki, Y., Salauddin, M., and Basha, H. A.: Characteristics of high-frequency gravity waves generated by tropical deep convection: Case studies, J. Geophys. Res., 114, D18109, doi:10.1029/2008JD011332, 2009.

Fovell, R., Durran, D., and Holton, J. R.: Numerical simulations of convectively generated stratospheric gravity waves, J. Atmos. Sci., 49, 1427-1442, 1992.

Fritts, D. C. and Alexander, M. J.: Gravity wave dynamics and effects in the middle atmosphere, Rev. Geophys., 41, 1003, doi:10.1029/2001RG000106, 2003.

Hierro, R., Pessano, H., Llamedo, P., de la Torre, A., Alexander, P., and Odiard, A.: Orographic effects related to deep convection events over the Andes region, Atmos. Res., 120-121, 216-225, doi:10.1016/j.atmosres.2012.08.020, 2012.

Green, J.: Atmospheric Dynamics. Cambridge Atmospheric and Space Science Series, Cambridge University Press, p. 17 and p. 90, 1999.

Kumar, K. K.: VHF radar observations of convectively generated gravity waves: Some new insights, Geophys. Res. Lett., 33, L01815, doi:10.1029/2005GL024109, 2006.

Kumar, K. K.: VHF radar investigations on the role of mechanical oscillator effect in exciting convectively generated gravity waves, Geophys. Res. Lett., 34, L01803, doi:10.1029/2006GL02-7404, 2007. 
Lane, T. and Reeder, M.: Modelling the generation of gravity waves by a maritime continent thunderstorm, Q. J. Roy. Meteorol. Soc., 127, 2705-2724, 2001.

Lin, Y.-L., Deal, R. L., and Kulie, M. S.: Mechanisms of cell regeneration, development, and propagation within a two-dimensional multi cell storm, J. Atmos. Sci., 55, 1867-1886, 1998.

Llamedo, P., de La Torre, A., Alexander, P., Luna, D., Schmidt, T., and Wickert, J.: A gravity wave analysis near to the Andes Range from GPS radio occultation data and mesoscale numerical simulations: Two case studies, Adv. Space Res., 44, 494-500, 2009.

Mapes, B. E. and Houze Jr., R. A.: Diabatic divergence profiles in western Pacific mesoscale convective systems, J. Atmos. Sci., 52, 1807-1828, 1995.

McLandress, C., Alexander, M. J., and Wu, D. L.: Microwave Limb Sounder observations of gravity waves in the stratosphere: A climatology and interpretation, J. Geophys. Res., 105, 1194711967, doi:10.1029/2000JD900097, 2000.

Mohankumar, K.: Stratosphere Troposphere Interactions an Introduction, Springer Science, Springer, 170 pp., 2008.

Pandya, R. E. and Alexander, M. J.: Linear stratospheric gravity waves above convective thermal forcing, J. Atmos. Sci., 56, 2434-2446, 1999.

Pfister, L., Chan, K. R., Bui, T. B., Bowen, B., Legg, M., Gary, B., Kelly, K., Proffitt, M., and Starr, W.: Gravity waves generated by a tropical cyclone during the STEP tropical field program: A case study, J. Geophys. Res., 98, 8611-8638, doi:10.1029/92JD01679, 1993b.

Preusse, P., Eckermann, S. D., and Ern, M.: Transparency of the atmosphere to short horizontal wavelength gravity waves, J. Geophys. Res., 113, D24104, doi:10.1029/2007JD009682, 2008.

Radhakrishna, B., Rao, T. N., Rao, D. N., Rao, N. P., Nakamura, K., and Sharma, A. K.: Spatial and seasonal variability of raindrop size distributions in southeast India, J. Geophys. Res., 114, D04203, doi:10.1029/2008JD011226, 2009.

Ramkumar, T. K., Niranjan Kumar, K., and Mehta, S. K.: Mesosphere-stratosphere-troposphere radar observations of characteristics of lower atmospheric high-frequency gravity waves passing through the tropical easterly jet, J. Geophys. Res., 115, D24109, doi:10.1029/2009JD013733, 2010.

Rao, P. B., Jain, A. R., Kishore, P., Balamuralidhar, P., Damle, S. H., and Viswanathan, G.: Indian MST radar: 1. System description and sample vector wind measurements using ST mode, Radio Sci., 30, 1125-1138, doi:10.1029/95RS00787, 1995.
Salby, M. L. and Garcia, R. R.: Transient response to localized episodic heating in the tropics. Part I: Excitation and short-time near-field behavior, J. Atmos. Sci., 44, 458-498, 1987.

Schmidt, T., de la Torre, A., and Wickert, J.: Global gravity wave activity in the tropopause region from CHAMP radio occultation data, Geophys. Res. Lett., 35, L16807, doi:10.1029/2008GL034986, 2008.

Sentman, D. D., Wescott, E. M., Picard, R. H., Winick, J. R., Stenbaek-Nielsen, H. C., Dewan, E. M., Moudry, D. R., Sao Sabbas, F. T., Heavner, M. J., and Morrill, J.: Simultaneous observations of mesospheric gravity waves and sprites generated by a midwestern thunderstorm, J. Atmos. Sol.-Terr. Phys., 65, 537550, doi:10.1016/S1364-6826(02)00328-0, 2003.

Simmons, A., Uppala, S., Dee, D., and Kobayashi, S.: ERA-Interim: New ECMWF reanalysis products from 1989 onwards, ECMWF News let., 110, 29-35, 2007.

Suresh, R.: Forecasting and nowcasting convective weather phenomena over southern peninsular India - Part I: Thunderstorms, Indian J. Radio Space, 41, 421-434, 2012.

Suresh, R. and Bhatnagar, A. K.: Pre-convective environment of pre-monsoon thunderstorms around Chennai - A thermo dynamical study, Mausam, 56, 659-670, 2005.

Torrence, C. and Compo, G. P.: A practical guide to wavelet analysis, B. Am. Meteorol. Soc., 79, 61-79, 1998.

Tsuda, T., Kato, S., Yokoi, T., Inoue, T., Yamamoto, M., VanZandt, T. E., Fukao, S., and Sato, T.: Gravity waves in the mesosphere observed with the middle and upper atmosphere radar, Radio Sci., 25, 1005-1018, doi:10.1029/RS025i005p01005, 1990.

Venkat Ratnam, M., Narendra Babu, A., Jagannadha Rao, V. V. M., Vijaya Bhaskar Rao, S., and Narayana Rao, D.: MST radar and radiosonde observations of inertia-gravity wave climatology over tropical stations: Source mechanisms, J. Geophys. Res., 113, D07109, doi:10.1029/2007JD008986, 2008.

Zhang, F., Wang, S., and Plougonven, R.: Uncertainties in using the hodograph method to retrieve gravity wave characteristics from individual soundings, Geophys. Res. Lett., 31, L11110, doi:10.1029/2004GL019841, 2004. 